\title{
IMPACT ANALYSIS OF RURAL INTERVENTIONS BY SKDRDP: A CASE OF KISAN MELAS
}

\author{
B. Venkatraja* and S. N. Prasad**
}

\begin{abstract}
In recent decades, non-government organisations (NGOs) increasingly play multiple roles effectively while acting as the bridge between the government organisations (GOs) and the grassroots population. Hence, the government is increasingly relying on these organisations in reaching many of the rural development schemes and financial inclusion drive at the village level. Shri Kshetra Dharmasthala Rural Development Project (SKDRDP) is one such leading NGO which strives towards transforming the lives of rural people through several rural intervention programmes. One of the several rural intervention programmes of SKDRDP to attain collective sustainable rural development is Krishi Melas (Kisan Melas/agricultural fairs). SKDRDP organises Krishi Melas since 1984 at different levels and intervenes in the lives of farmers and rural people with the objective of inclusive and balanced rural development. The present research attempted to study SKDRDP Krishi Mela Model, strategic perspectives of various activities under Krishi Melas, the mechanism of executing the events and more significantly the extent to which Krishi Melas have impacted the rural community. The study has procured data from secondary and primary sources. The study is exploratory and empirical in nature. While analysing the primary data, Exploratory Factor Analysis (EFA) and Confirmatory Factor Analysis (CFA) are used. The model extracted from this exercise reveals that Krishi Mela interventions have a significant impact on the empowerment of rural people, agricultural development, financial and economic well-being, and also immensely contribute to building social capital. The results of the study have significant implications for the organisation and policymakers.
\end{abstract}

Keywords: Krishi Mela, Kisan Mela, Agri-fair, Rural Development, SKDRDP, Rural Empowerment.

\footnotetext{
*Assistant Professor-Economics, Shri Dharmasthala Manjunatheshwara Institute for Management Development (SDMIMD) Mysuru, Karnataka-India.

**Professor- Strategy \& General Management, Shri Dharmasthala Manjunatheshwara Institute for Management Development (SDMIMD) Mysuru, Karnataka-India.

Acknowledgement: This research was funded by Shri Dharmasthala Manjunatheshwara Institute for Management Development (SDMIMD). The authors are grateful to the Director Dr. N. R. Parasuraman and the Management of SDMIMD. Support of Dr. Srilakshminarayana G., Associate Professor- Quantitative Methods, SDMIMD, Mysuru in data analysis was invaluable.
} 


\section{Introduction}

India is predominantly a country of villages. As estimated by the Census (Gol, 2011) the country has 640,867 villages with nearly 833.1 million inhabitants which constitute 68.84 per cent of the country's population. Despite being the 'backbone' of the economy, rural India lags way behind urban India in growth arena. The per capita income in rural India was Rs. 40,772 against Rs.1,01,313 urban India (Gol, 2016). Underdevelopment of villages affects national growth to a larger extent. Owing to the backwardness of rural India, it is becoming imperative to achieve rapid rural development to sustain the macro development. Since the beginning of the planning era in 1951, due emphasis has been laid down by the successive governments at Centre and States to focus on rural development. Despite huge budgetary allocations over the decades, the growth of rural economy was staggering. Of late, the nation and the policymakers have realised that their programmes would be successful only if they ascertain the people's participation. In an attempt to garner the support and participation of the rural population, the government started working with Voluntary Agencies (VAs) and non-government organisations (NGOs) which work at the grassroots level. The first official attempt to collaborate with the NGOs was in 1986 by setting up the Council for the Advancement of People's Action and Rural Technology (CAPART). With the setting up of CAPART, funds were granted to NGOs for their rural initiatives, and government schemes and programmes were implemented through NGOs. Since then, NGOs were involved in designing and implementing the successive Five-Year Plans.

NGOs increasingly play multiple roles as the bridge between the government organisations (GOs) and the grassroots population. As NGOs work with the grassroots, it is believed that they accurately map up the expectations of the people and understand the local realities. This special characteristic feature of NGOs makes the government to increasingly rely on these organisations in reaching many of the rural development schemes and financial inclusion drive at the village level. Shri Kshetra Dharmasthala Rural Development Project (SKDRDP) is one such leading NGO which strives towards transforming the lives of rural people through several rural intervention programmes. Dr. D. Veerendra Heggade, Chairman of SKDRDP envisioned that through SKDRDP all sections of rural society integrate and become partners in collective sustainable development. Founded in 1982 in a small village of Belthangady taluk of Karnataka State, SKDRDP has stretched its rural development activities to entire Karnataka State and Kasaragod district of Kerala State and today it has 37.24 lakh clients.

The major objective of SKDRDP is to achieve rural development and it visualises rural development holistically. Small and marginal farmers, agricultural labourers, rural women, rural artisans, people engaged 
in rural industries and other disadvantaged population constitute the primary stakeholders of SKDRDP. Horizontal integration of social, cultural and economic aspects of well-being has made SKDRDP adopt a multi-dimensional rural development strategy. Rural dwellers are also vertically integrated with the various government welfare schemes. Being a development partner and integrator, SKDRDP works as the Banking Correspondent and Business Facilitator to many nationalised banks connecting rural people with the banking products, works as corporate agent of Life Insurance Corporation (LIC) India Ltd., aggregator for National Pension Scheme (NPS) under Central government and Customer Hire Service Centre to rent out farming machinery in collaboration with Government of Karnataka. This strategic approach of SKDRDP has enabled it to adopt integrated rural development model which results in holistic development, not mere income growth. As SKDRDP believes in the interwoven relationship between social, cultural and economic dimensions of rural living, it interferes in several areas to enable its development partners to raise up their capabilities to lead the life as they want to lead with dignity.

The SKDRDP intervenes in the lives of poor people in several areas of development such as agricultural development, community development, social and cultural development, economic development, sustainable development and skill development. Formation of SHGs, provision of microfinance, setting up of skill development centre, creation of forums for public awareness on social, cultural, legal and economic issues, support to education, health, sanitation, clean and renewable energy by creating awareness and needful infrastructure, organising health camps and de-addiction camps are the other extension programmes of SKDRDP. Organising agricultural fairs frequently in different project locations is one of the methods of interventions of SKDRDP which has the objective of attaining rural development. This study attempts to evaluate the impact of Krishi Melas on the wellbeing of the rural population.

\section{Research Methodology}

Nature of the Study: The present study is descriptive and empirical in nature. The descriptive study on the contribution of Krishi Melas to the rural development has been pursued in arriving at appropriate research hypotheses and such hypotheses are tested with an empirical approach.

Data Collection: Essential data required for the study are procured from both secondary and primary sources. The secondary data and information which were very crucial for the descriptive analysis upon which the hypotheses were developed are collected from annual reports and other publications of SKDRDP. The primary data are collected through a two-stage process.

At Stage-l, data are collected on the organisational perspectives (SKDRDP) from 
the authorities of SKDRDP through direct personal interview method. The officer-incharge of Kisan Mela at different levels of the SKDRDP organisational structure, i.e. head office, regional office, district office and village level offices are interviewed. The objective of the interviews was to understand the organisational structure of SKDRDP, the various rural development initiatives of SKDRDP, the rural intervention strategies, practices of financial management, strategic planning for Krishi Melas, implementation of strategic plans, the expected results and the achieved results of organising various Krishi Melas. This also enabled in gathering organiser's perspective on the impact of Krishi Mela on the well-being of rural people.

At Stage-II, a household survey through non-probability sampling technique is carried out. The target population are the participants of various Krishi Mela events organised by SKDRDP. The primary investigation has been carried out at Mysore and Chamarajanagar districts of Karnataka State. The farmers of these two districts were chosen for study for two reasons: Firstly, both districts have large population depending on rural occupations for livelihood and secondly, SKDRDP had conducted Krishi Melas in both districts in the past year. The study has collected data using a questionnaire from 108 rural households at villages of Chamarajnagar district and from 152 households of different villages of Mysore district. Thus, the survey has collected data from 260 rural households that participated in SKDRDP Kisan Melas.
Questionnaire, Scaling and Testing the

Reliability: In order to measure the perception of the informants, a questionnaire was designed and responses were collected through direct personal interview method in the villages of Mysore and Chamarajanagar districts. The first part of the questionnaire consisted of demographic aspects of the respondents and the second part consisted of the questions related to the magnitude of the impact of Kisan Melas on various aspects of living such as agriculture, social security, empowerment, economic and financial, general, etc. Each of the questions in the second part was considered as observed variables and they were measured on a 3-point Likert scale.

While understanding the perception of the individuals, it is imperative to build a questionnaire containing the variables on which responses are collected. In order to ensure the internal consistency among the variables in measuring the construct and measuring the reliability of the questionnaire, Cronbach alpha proposed by Cronbach (1970) has been applied. As per the Cronbach (1970) rule, the value of alpha close to one is considered to be excellent and a value less than 0.50 is not desirable.

Tools for Analysis: The study has employed descriptive statistical tools like trend analysis, graphical and diagrammatic analysis leading to the formation of hypotheses. In the second stage, empirical analysis is deployed for analytical testing through Exploratory 
Factor Analysis (EFA) and Confirmatory Factor Analysis (CFA). The detailed methodological description has been provided along with the result analysis.

\section{Review of Literature}

Honnappa and Basupattad (2016) studied intensively the mechanisms of SHGbank linkage programme of SKDRDP leading to financial inclusion. The study reveals that apart from the provision of rural credit, other philanthropic initiatives of SKDRP build up the confidence and skills required to start business ventures leading to a sustainable livelihood. Even Shetty and Pinto (2015) have examined the success rate of financial inclusion adopting SHG-BLP model by SKDRDP. It is evident that both the studies emphasise mainly on the financial inclusion and hence these studies are partial. As human development is a comprehensive concept, well-being cannot be measured only through credit availability rather multi-dimensions of well-being such as social well-being, empowerment, safety and security, organisational participation, etc., need to be incorporated. This creates scope for examining whether SKDRDP's interventions lead to comprehensive development.

In a similar study, Priyakumari (2015) has noted that the SKDRDP initiatives have transformed the lives of women. The study reveals that the standard of living of the participatory women has improved drastically since their joining of SKDRDP. The income of women has risen, savings increased and their purchasing power has improved. In addition to economic development, the study observed an improvement in capabilities of women under SKDRDP. They have gained selfconfidence, can speak freely in front of a large group of people, and they enjoy a better status in society. They are capable enough to play a greater role in household decision-making. However, the study is descriptive and the conclusions are hypotheses and they are not tested analytically.

Belli and Raghvendra (2014) analysed the role played by SKDRDP in sustainable rural development through microfinance. The report of the study reflects that the formation of self-help groups (SHGs) by SKDRDP and linking such SHGs to banks for microfinance accelerates the process of financial inclusion of rural population. The study outcome also exhibits that SKDRDP plays a limited role in marketing the products of SHGs. The conclusion of this study raises further questions as SIRI Gramodaya Yojana under SKDRDP provides ample marketing opportunities to the products produced by the SHG members. Further, SKDRDP also organises Krishi Melas at all levels, again provides a platform for marketing of products grown by SHG members. Hence, the study of Belli \& Raghvendra (2014) is ambiguous and demands a fresh investigation on the subject matter.

Akshatha and Akash (2014) evaluated the relevance of rural development programmes of SKDRDP in rural areas of Shivamogga 
district. Similar to the findings of other studies, this paper also observes that the rural intervention strategies of SKDRDP were very effective in transforming the lives of the people benefited. The training and activities toward entrepreneurial skills were the prominent factors leading to success. This apart, as the author says "spirituality and devotion to God makes people work with faith and belief, which is the reason for its rapid growth in all rural areas." This study also has arrived towards conclusion based on descriptive study without empirically testing.

D'Souza et al. (2013) analysed the effectiveness of SKDRDP's Business Correspondent (BC) Model for inclusive growth. The study concludes that the BC Model is the best tool to attain sustainable development of the country. Again, the focus of the study was laid down prominently on the credit delivery and financial inclusion and the study was descriptive. Thus, the study resulted mainly in opinion formation and such opinions are not tested for validity by the authors.

Joshi (2012) has analysed the role of management and leadership of the NGOs in rural development. This study was carried out with special reference to SKDRDP. The author arrives at the inference that the practical wisdom and leadership of the Chairman Dr. D. Veerendra Heggade and the professional management of the SKDRDP are the major contributing factors to success. Joshi makes a very interesting observation in his study referring to Harper- "In SKDRDP, Harper noticed a unique combination of development, divinity and dharma which became possible on account of inspiring leadership qualities of Veerendra Heggade." In the words of Harper as quoted in Joshi (2012), "SKDRDP is essentially a traditional community-based institution, inspired by a local God, and relying on a local institution and locally recruited staff, to serve local people. Its competence is homegrown rather than professionals, and Dr. Heggade has whenever possible resisted the employment of development professionals."

Shylendra et al. (2012) made an indepth descriptive study on SKDRDP and arrive at the conclusion that it is the model with certain positive lessons worthy of replication in microfinance. The authors attribute the success of SKDRDP to various factors such as committed leadership of the NGO, values of its spiritual moorings and altruistic principles, thrust on not-for-profit approach and adoption of an integrated approach to livelihood by combining interrelated developmental inputs.

The literature survey exhibits that hardly any study paid attention to investigate the beneficiaries' perspectives. Again, it is found that no study has been pursued so far on the individual intervention schemes of SKDRDP and their impact on the socio-economic wellbeing of the society. This, in turn, fails to elicit the effectiveness of individual intervention tools. Thus, this paper aims at filling this vacuum created by the past studies on SKDRDP. 
SKDRDP Model of Agricultural Fair - An Extension Technique of Development

\section{Evolution of Agricultural Fair}

The available limited literature shows the historical linkage of agricultural fairs to the Eastern Mediterranean before the birth of Christ. The book of Ezekiel supposedly written in about 588 B.C. describes how the fairs were being organised in Ninevah, Athens, Rome and Mecca. In the early Christian era, the church took an active part in organising fairs and found that organising fairs were the ways of generating revenues to church and thus the fairs underwent an ideological transformation from religion to commercial. Over the centuries, the fairs evolved from barter exchange to sales and gradually filled with fun and entertainment. The history records that the first North American fair was organised in 1765 in Windsor at Nova Scotia which is operational even today. In 1792, the Niagara Agricultural Society presented the first fair in Canada which also remains functional.

In 1807, Elkanah Watson, a farmer of Pittsfield, Massachusetts organised the first agricultural fair by presenting a cattle show. The same had evolved as Berkshire County Fair by 1811 which featured a procession of four thousand cattle, a music band, also included displays of local industries and artisans. Elkanah Watson, for his efforts rightfully earned the title, "Father of US agricultural fairs". He had brought a level of transition by making the event a competition than a mere exhibition of verities of animals. It is also recorded that in $1841, \mathrm{New}$ York organised the first state agricultural fair in Syracuse. The agricultural fairs during the early eighteenth century provided opportunities to rural families to see beforehand the best available recent most agricultural techniques, equipment, crops, and livestock. During the nineteenth century, agricultural fairs evolved by incorporating a wide range of educational, recreational, competitive and social activities into their programmes making the event more significant and comprehensive. The educational dimension of the agricultural fairs was a significant development in American agricultural fairs during the nineteenth century. Several colleges and universities opened schools of agriculture. Effective means of growing food became the basis of scientific inquiry. The schools and research centres of agricultural universities started discovering scientific farming methods, technologies, high yielding verities of seeds, farm machinery and equipment, fertilisers, etc., and they were on exhibition at the fairs.

Arthashastra written by Kautilya makes reference to agricultural fairs being organised in ancient India. Agricultural fairs though were being organised in different locations in India, the most authentic agricultural fair which took place on a large and diversified scale was as recorded in 1864 in Calcutta organised by the Government of Bengal. The exhibition had three categories with livestock, agro-machinery and implements, and agro- 
products. The literature recorded the grand success of the Calcutta agricultural fair, with an estimated 70,000 people participating in it. This success led to the organisation of local agricultural fairs widely at Bengal, Bihar and Orissa before being spread to rest of India. The Bengal agricultural fair laid the foundation for several government and nongovernment organisations and agricultural universities of India to organise agricultural fairs and exhibitions in the late nineteenth and twentieth centuries.

Drawing from these models, SKDRDP has been organising Krishi Melas with modifications, on a regular basis in different locations of its project area since 1984. SKDRDP organised the first Krishi Mela in February, 1984 in Venur, a village of Belthangady taluk. During the initial years of 1984 to 1989 , Krishi Mela was in the formative phase. During this period, Krishi Mela was being organised at the cluster level (a group of 5 to 15 villages). Considering the in-depth reach of the events to the rural people and the mass acceptance of the first Krishi Mela, SKDRDP held Krishi Melas twice a year in different villages during the formative phase. The Krishi Mela organised in January 1998 at Belthangady was the first taluk level meet. Realising the growing needs of rural people and enable them to build up their capabilities, the SKDRDP stretched its Krishi Melas gradually to the neighbouring taluks of Dakshina Kannada district since 2000 and in the due course to all the districts of Karnataka
State. Krishi Melas are now held at taluk, district, regional and State levels throughout the year with a special focus on backward locations of its project areas. So far, SKDRDP has organised 37 State level Krishi Melas and the latest was organised at Bailahongala, Belgaum district in January 2017. More than three lakh farmers and rural people participated in the three-day event.

\section{Objectives and Perspectives of Krishi Mela Interventions}

The major objectives of Krishi Mela appear to be generating direct and indirect employment to rural people, provide income security, improve standards of living and empower to lead the kind of life of their choice with dignity. It also aims at introducing modern agricultural practices, government schemes, bring decision-makers and farmers together on a common platform and promote the skills of farmers. These diverse objectives of Krishi Mela interventions of SKDRDP are bound by three major perspectives: economic perspective, social perspective and community perspective.

\section{Economic Perspective}

- To provide exposure and transfer of technology in agriculture, horticulture, sericulture, forestry, fishery, etc.

- To provide access to inputs such as seeds, manure, plant protection means, equipment and machinery

- To provide market linkage between buyers and sellers 
- To create a forum for an interface between government departments, NGOs, banks and rural people

- To mould and articulate public opinion on government policies affecting the rural economy

- To create awareness and access to non-renewable energy for sustainable development

- To promote rural entrepreneurship

\section{Social Perspective}

- To promote cultural identity by exhibiting rural customs, traditions and art-talent recognition

- To provide awareness to rural people on healthy living practices, family norms, women and child care and traditional medicare

- To demonstrate and to provide access to technology on community health and sanitation

- To create awareness and provide access to facilities of de-addiction

- To campaign against social evils like dowry and gender discrimination

- To enable women empowerment

\section{Community Perspective}

- To develop community assets/ infrastructure

- To create awareness on conservation and management of community resources
- To promote and recognise community institutions

\section{Strategic Techniques of Krishi Mela for Rural Intervention}

SKDRDP intervenes in the lives of rural people through Krishi Mela as one of the techniques. Krishi Melas of SKDRDP intervene in rural development through multiple techniques.

One of the most influential and powerful intervening techniques of SKDRDP Krishi Mela is organising exhibitions covering areas of agriculture, horticulture and floriculture. The universities, research institutes and line departments of the government put up exhibition stalls to introduce modern farm machinery and equipment, methods of cultivation, new crops, scientific cultivation, modern and economical methods and machinery of irrigation, high yielding varieties of healthy seeds, organic manures, organic pesticides, etc. The $37^{\text {th }}$ State level Kisan Mela held at Bailahongala, Belgaum had more than 500 exhibition stalls. Such exhibition stalls help the business entities, marketing companies, manufacturers, technocrats, government officers, etc., to facilitate the reach of their products and concepts to ultimate customers.

The Krishi Melas have centres demonstrating the operation, areas of utility and efficiency of the new farm machines and tools. This also involves live demonstrations of artistic carpentry. Further, they also display 
several items which are categorised under five broad product lines: agriculture and horticulture technologies, animal science and fisheries, farm machinery, agriculture and horticulture inputs and service organisations. Krishi Melas also have several display counters on renewable energy equipment relating to solar, gobar (cattle dung), and wind. This provides first-hand information on the costeffectiveness of cultivation using renewable energy. This indirectly promotes the goal of environmental sustainability. Further, displays are also on the categories varieties of valueadded products. This would encourage people to take up self-employment under valueadded products through economical but scientific methods.

To promote animal husbandry, Krishi Melas organise livestock show. This provides a forum for farmers to bring their cattle and dogs to the show. Such shows have multiple benefits such as encouraging progressive farmers towards animal husbandry, creating a market for the farmers to sell their cattle, offering plenty of verities to the buying farmers, and avoiding middlemen and commission agents in the trade and ensure a fair price.

The Krishi Melas have special centres for farmer consultancy. The experts and authorities from the departments of agriculture, horticulture, floriculture and sericulture are available in such centres and the farmers can have direct interactions with them. The queries of the farmers relating to the mentioned departments on issues ranging from pest control, irrigation, fertilisation, multiple cropping, mixed farming, use of farming techniques, methods and machines, seeds to animal husbandry, etc., are addressed to the satisfaction by the experts of the centre. The Krishi Melas arrange this consultancy to the farmers at free of cost. Such consultancy centres significantly contribute to rural development by guiding the farmers on the right path.

The Krishi Melas provide a forum for direct interactions between farmers and agricultural scientists. This provides a platform for scientists to share the recent trends and advances in farming methods, techniques and technologies, organic farming, techniques of irrigation, etc. Further, this also enables farmers to bring the practical problems encountered by them on the field to the attention of the scientists, which would assist towards further scientific advancement.

One of the significant strategic ways of the intervention of Krishi Mela is inviting policymakers to the Melas and makes them interact with the rural people. This provides a forum to the farmers and rural poor people to take their grievances to the policymakers and urge collectively to redress. Rural infrastructure such as rural road connectivity, housing, rural electrification, drainage, sanitation, drinking water, irrigation, etc., are the prominent issues among others for discussions. Using the platform of Krishi Melas, the Department of Field Publicity displays agri-film to the farmers. 
The studies exhibit that Krishi Melas have a drastic impact on policymakers towards rural development.

Krishi Melas organise lectures and discussions by the experts in the field to the benefit of the farmers on various specific issues including dairy farming, working with nature, seed protection and development, flood irrigation, soil protection, small irrigation projects, deciding crops, use of technology, government schemes, mechanisation, water bodies, financing agriculture, educating with banking transactions, avenues of selfemployment, de-addiction, etc. Every Krishi Mela lays emphasis on personal health and hygiene. These sessions are educative, awareness creator and motivator to the participant poor farmers.

Krishi Melas have special desks of nationalised banks promoting the different agricultural credit facilities and insurance schemes to the farmers. This is a significant advancement towards providing institutional credit to the rural sector freeing the poor from the clutches of moneylenders who impose exploitative terms and conditions.

Krishi Mela of SKDRDP targets to involve women in every stage- may it be in organising the programme, running the various events during the programme, exhibition stalls of women made products, participation of thousands of women SHGs, etc. Krishi Mela aims at women empowerment. This is a very strategic technique of Krishi Mela since women empowerment leads to family empowerment which in turn leads to societal improvement.

The members of SKDRDP SHGs work as volunteers in organising the Krishi Melas. The SHG members arrange the venue of the Krishi Mela intact, coordinate the entire proceedings of the events under Krishi Mela, and actively participate in the various sessions. This not only allows mass participation but also instils ownership among the rural SHG members. Their participation turns the event to a grand success.

SKDRDP connects local people with the culture through Krishi Melas. The folk art, folk dances, folk songs, dramas, etc., are performed by the local people. Further, Krishi Mela also organises competitions on traditional and native games. This enables rural people to exhibit their talent and skills, and re-orient the younger generation with the cultural heritage of the society. Krishi Mela is a source of entertainment, in addition to build up confidence and leadership qualities among the artists. The building of emotional bond with local culture and tradition by Krishi Mela also makes people associate themselves voluntarily with all the events of Krishi Mela and work towards self-dependency and development.

Krishi Melas are widely used as a platform by the SKDRDP to identify the progressive farmers and felicitate them with awards and 
prizes for the incredible achievements in the field of farming. Recognising the local farmers has motivational and inspirational perspectives.

Krishi Mela brings together all development partners as stakeholders of Krishi Mela. Rural people are the primary stakeholders while the secondary stakeholders of Krishi Mela include authorities of local, district and state administration, local elected representatives of democratic bodies, policymakers, formal banking and financial institutions, universities and research institutes, voluntary organisations, local educational institutions, mutts and religious leaders/pontiffs of the region, etc. Making collective decisions for rural development keeping all the stakeholders in the loop has made Krishi Mela a serious peasant movement in Karnataka.

The Krishi Mela events have been kept purely non-political and completely secular. It does not support the ideologies of any political party. Leaders of all political parties are stakeholders of the events. Further, Krishi Melas do not propagate any religion. They are open to all religion, caste, class, creed and gender. This again seems to be the major strategic approach of rural intervention leading to mass acceptance and participation in Krishi Melas and contributing to peaceful and prosperous societies.

\section{Unique Features of SKDRDP's Agri-Fair Model}

The Krishi Melas organised regularly by SKDRDP are drawn from the American model, Bengal model as well as from university model. Despite being borrowed from other models SKDRDP's Krishi Mela is unique as it introduced innovative practices. Further, the borrowed concepts are customised drastically to suit the local needs and to the current growth requirements. The SKDRDP Krishi Mela stands out unique on some grounds as under:

- The benevolent leadership of Dr. D. Veerendra Heggade sparks the current among the stakeholder network infusing the positivity in the entire chain which separates SKDRDP Krishi Mela from other agri-fair models.

- The SKDRDP Krishi Mela is rather a people-driven event as the entire event is supported, managed and organised by people organisations. This is in contrast to the government or university-driven Krishi Melas.

- $\quad$ SKDRDP runs Krishi Mela throughout the year in different locations at different levels.

- $\quad$ SKDRDP Krishi Melas have a diversified basket of products for display and sale.

- $\quad$ Krishi Mela events cover several micro aspects such as health, hygiene, sanitation, housing, farming, fair marketing, upskilling for sustainable macro development. 
- Unlike other organisations and universities, as SKDRDP focus on preserving and promoting social ethos, culture and ethical values.

\section{Impact of Agricultural Fairs on Rural Development - Data Analysis and Results}

The study has proposed to build a model that identifies the level of impact that Kisan Melas have on each of the factors, which are considered to be indicators of rural development. It was also essential to build a model that would ascertain the impact of each of the factors on the observed aspects related to the development of farmers in different dimensions of their life as well. The model is built at two stages by estimating factor analysis technique. In the first stage, Exploratory Factor Analysis (EFA) has been used and in the second stage, Confirmatory Factor Analysis (CFA) has been applied. EFA is used to find the growth factors related to Kisan Melas. The process has considered the observed variables and based on the correlations between the variables, they have been combined to form factors. The correlations between the variables are computed based on responses of the informants and the significant correlations between set of variables are reflections of the viewpoints of rural people related to the closeness of the variables to each of the factors. After the variable-factor structure is identified, a model is built to study the impact of Kisan Melas on the development of the farmers. To test the model built, Confirmatory Factor Analysis (CFA) is used. While EFA gives the factors to build the model, CFA helps to test the model built. In the current study, CFA is used to test the model proposed to study the impact of Kisan Melas on the multidimensional development of rural people.

\section{Testing the Reliability of Questionnaire}

The questionnaire has been tested for reliability by applying Cronbach alpha and it is found that the questionnaire used for the study has the desired level of reliability in understanding the impact of Kisan Mela interventions on rural development. The Cronbach alpha value in this case is 0.931 , and the questionnaire falls into the excellent category. Thus the study has considered the same questionnaire without any changes for the final survey.

\section{Exploratory Factor Analysis (EFA)}

In the current study, EFA has been used to find the variable-factors structure to understand the impact of Kisan Melas on the capabilities of rural people. Upon confirming the reliability of the questionnaire, data has been collected from the informants and the collected data are loaded for testing of reliability.

\section{Testing the Reliability of Data: KMO Index and Bartlett-Test}

The reliability of data is verified through standard statistical procedures. Firstly, KaiserMeyer-Olkin (KMO) index has been measured. Kaiser-Meyer-Olkin (KMO) index is a measure of support the sample provides to the factor 
analysis. It measures the sampling adequacy for each variable in the model and for the complete model. It measures the proportion of variance among variables that might be common variance. The lower the proportion, the greater the suitability of data to factor analysis. Kaiser (1970) advocated that KMO above 0.7 is acceptable. The KMO index derived for the current study from the application of the methodology proposed by Kaiser is 0.905 which indicates that the sample considered for the study supports the conduct of factor analysis.

The basic principle on which the factor analysis constructed is the correlations between the variables. If the correlations between the variables are not significant, one cannot use the factor analysis and the testing has to be done for all the pairs of correlations. For this, one has to test whether the population correlation matrix (that contains all pairs of correlation) is equal to identity matrix and this is the null hypothesis. If the null hypothesis is rejected, then one can proceed to construct the factor analysis. Bartlett test for Sphericity (1937) is used to test the significance of the correlation matrix. The result of the test presented in Table 1 provides evidence to reject the null hypothesis and hence concluded that the correlation matrix is significant and factors analysis can be used.

Table 1: Bartlett Test for Sphericity

\begin{tabular}{|l|l|}
\hline Approx. Chi-square value & P-value \\
\hline 4717.575 & 0.0001 \\
\hline
\end{tabular}

Source: From data analysis
Upon testing the validity of the data of the study by KMO index and Bartlett-test, factor analysis is applied and the following section gives the results of the same.

\section{Communalities}

Communalities are computed for each of the variables and interpreted as the proportion of variance, in that variable, explained by the factors extracted. The strength of the factor analysis can be assessed by the communalities. If for any variable, the communalities are less than 0.5 , then it is advised to exclude those variables. It is because they cannot be explained better by the factors. Table 2 presents the communalities for the study area and it could be noted that, for all the variables, the communalities are more than the required cut-off. Improved cultivation techniques, adapting to modern agricultural practices, adopting scientific farming, farming skills and the rising standards of living of rural people are the variables explained to a larger size by agrifairs of SKDRDP. Learnings of rural people from agri-fairs appear to be low on the variables such as de-addiction, resource conservation, health awareness and social status of the rural people, while the other variables are defined moderately by the regular agri-fairs of SKDRDP.

\section{Total Variance Explained}

Based on the total variance explained by the factors, the variables are replaced with the factors extracted. For the current study, Table 3 gives the total variance explained for 
the study area. As per the rule of thumb, the minimum cut-off has to be 65 per cent which will have interpretations and results. It could be observed from the results that five factors are extracted for the initial growth model and the five factors together explain 68 per cent of the variance in the impact of agri-fairs on the development of rural people.

Table 2: Communalities for the Study Area

\begin{tabular}{|l|c|}
\hline Variable & Communalities \\
\hline Farming Knowledge & .855 \\
\hline Farming Skills & .825 \\
\hline Agri-Practices & .866 \\
\hline Cultivation Techniques & .869 \\
\hline Scientific Farming & .841 \\
\hline Organic Farming & .595 \\
\hline Conservation & .548 \\
\hline Health Awareness & .570 \\
\hline Hygiene & .739 \\
\hline Sanitation & .697 \\
\hline Education & .649 \\
\hline De-addiction & .529 \\
\hline Social Status & .572 \\
\hline Responsibility & .664 \\
\hline Meaning \& Value & .586 \\
\hline Freedom & .672 \\
\hline Decision Making & .632 \\
\hline Self-Dependency & .581 \\
\hline Self-Employment & .587 \\
\hline Income & \\
\hline
\end{tabular}

\begin{tabular}{|l|c|}
\hline Finance & .604 \\
\hline Savings & .658 \\
\hline Standard of Living & .802 \\
\hline Security \& Confidence & .724 \\
\hline Happy Home & .705 \\
\hline
\end{tabular}

Source: Primary data analysis.

Table 3: Total Variances Explained

\begin{tabular}{|c|c|}
\hline $\begin{array}{c}\text { Total Variance } \\
\text { Explained }\end{array}$ & $\begin{array}{c}\text { Factors Extract- } \\
\text { ed }\end{array}$ \\
\hline $68 \%$ & 5 \\
\hline
\end{tabular}

Source: Primary data analysis.

\section{Component Matrix}

Upon the total variance explained meets the required cut-off, the next consideration is on the factor loadings. Factor loadings are the correlations between the variables and the factors. The minimum cut-off for a variable to be associated with a factor is 0.4 and above. Table 4 gives the factor loadings for the study area. It could be noted that the component matrix of all the variables is above the minimum cut-off. Learning of new cultivation techniques from agri-fairs has the highest association with the factor extracted (agriculture), whereas awareness on water and soil conservation measures has caused the lowest variability by the SKDRDP agrifairs. Based on the component matrix, factors are extracted. Considering the variables that are under one group, the factors have been appropriately titled and the same is presented in Table 5. 
Table 4: Factor Loading Matrix

\begin{tabular}{|c|c|c|c|c|c|}
\hline \multirow[t]{2}{*}{ Variable } & \multicolumn{5}{|c|}{ Factors } \\
\hline & 1 & 2 & 3 & 4 & 5 \\
\hline Farming Knowledge & .896 & & & & \\
\hline Farming Skills & .886 & & & & \\
\hline Agri-Practices & .903 & & & & \\
\hline Cultivation Techniques & .910 & & & & \\
\hline Scientific Farming & .887 & & & & \\
\hline Organic Farming & .672 & & & & \\
\hline Conservation & .519 & & & & \\
\hline Health Awareness & & & .688 & & \\
\hline Hygiene & & & .794 & & \\
\hline Sanitation & & & .780 & & \\
\hline Education & & & .724 & & \\
\hline De-addiction & & & .590 & & \\
\hline Social Status & & .661 & & & \\
\hline Responsibility & & .711 & & & \\
\hline Meaning \& Value & & .699 & & & \\
\hline Freedom & & .743 & & & \\
\hline Decision Making & & .690 & & & \\
\hline Self-Dependency & & .609 & & & \\
\hline Self-Employment & & & & & 697 \\
\hline Income & & & & .526 & \\
\hline Finance & & & & .742 & \\
\hline Savings & & & & .726 & \\
\hline Standard of Living & & .720 & & & \\
\hline Security \& Confidence & & .665 & & & \\
\hline Happy Home & & .676 & & & \\
\hline
\end{tabular}

Source: Primary data analysis. 
Table 5: Factors Identified

\begin{tabular}{|c|c|}
\hline S. No. & Factor Title \\
\hline 1 & Empowerment \\
\hline 2 & Agriculture \\
\hline 3 & Social Capital \\
\hline 4 & Financial \\
\hline 5 & Self-Employment \\
\hline
\end{tabular}

Source: Primary data analysis.

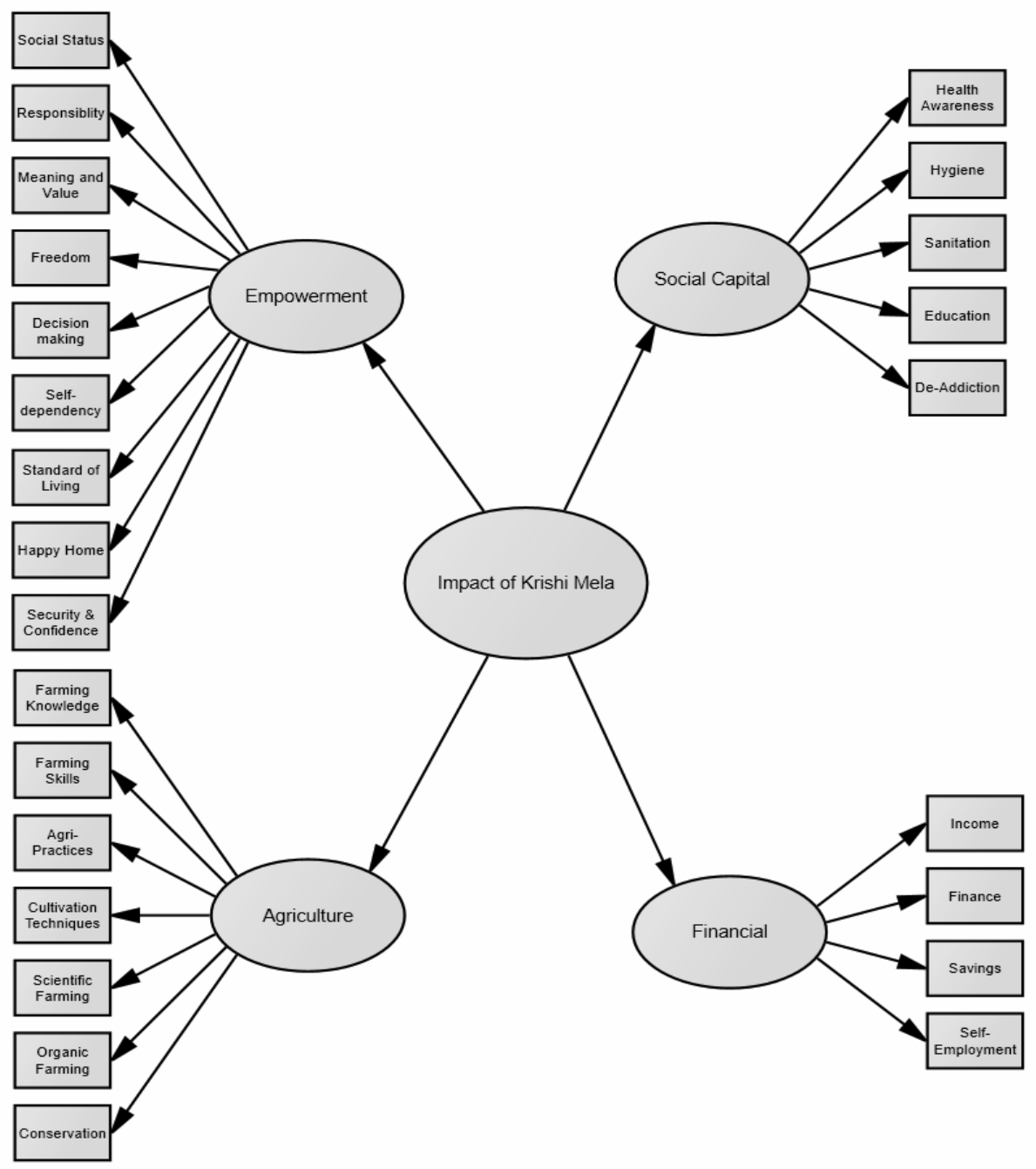

Source: Extracted from primary data using EFA.

Figure 1: Initial SKDRDP Agri-Fair Growth Model 
Using the EFA, the initial agri-fair growth model for the study area has been generated and is presented in Figure 1. The initial model presumes that agricultural fairs may impact four factors related to empowerment, social capital, agriculture and financial status. The model predicts that organising agricultural fairs would have led to the empowerment of rural people by positively impacting their social status, responsibility to society and family, realising meaning and value of own life, freedom, ability to make decisions for self and family, self-dependency, standards of living, peaceful family and security and confidence. It is also assumed that agri-fairs would have contributed to agricultural development in the region by creating awareness on farming and farming skills, introducing modern agricultural practices and new cultivation techniques, teaching on scientific and organic farming, and sensitising towards resource conservation. Agricultural fairs are expected to raise the social capital by spreading awareness on health, hygiene and sanitation, educate poor people with the significance of education and by creating de-addicted society. The financial status of the informants would also improve with agricultural fairs as it may lead to higher income, provide access to institutional credit, motivate to save and provide a platform to explore self-employment opportunities. No specific conclusions could be derived out of this model as it is extracted from EFA and is a hypothetical model. This model is tested for validation using CFA.

\section{Confirmatory Factor Analysis (CFA)}

The initial model is tested by running confirmatory factor analysis (CFA). In the process, the good fit of the model is tested, the regression weights of the factors/constructs and their associated variables are measured, the direction of regression paths between agri-fairs and factors and their variables are detected. Eventually, this statistical exercise has led to generating the final model of growth generating from agricultural fairs.

\section{Testing the Good Fit of the Model}

In order to identify the final model, the model fit indices such as CMIN/DF, RMR, $\mathrm{GFI}$, indices of baseline comparisons, RMSEA and PCLOSE are constructed. Table 6 gives a discussion on the actual values of such indices. CMIN gives an indication of whether the fit of the data to the proposed model is good. The hypothesis tested here is - the proposed model is close to the actual model- and the values of CMIN/DF are looked at to test this hypothesis. Values less than 2 or 3 indicate that the fit is a good fit (refer to Ullman, 2001, Schumacker \& Lomax, 2004). It could be noted that the actual value (1.313) is less than 2 and we conclude that the model has a good fit. This indicates that the covariance structure proposed is supported by the sample drawn.

The Root Mean square Residual (RMR), Goodness of Fit Index (GFI) and Adjusted Goodness-of-Fit Index (AGFI) are presented in Table 6. A value of RMR close to zero is considered to be a good fit $\mathrm{Hu}$ and Bentler 
(2009)) and the actual GFI value measured for the model is in the acceptable limit. Also, the values of GFI and AGFI (see $\mathrm{Hu}$ and Bentler (1995) indicate that the model is a good fit. Comparative Fit Index (CFI) and Tucker-Lewis index (TLI) have index values close to 1 which is considered as a good fit.

Root Mean Square Error of Approximation (RMSEA) was proposed by Steiger and Lind (1980) and a value of 0.0001 (see, Hu and Bentler (1999), Browne and Cudeck (1993)) indicates a good fit between the hypothesized model and the observed data. In addition to this, the PCLOSE value as suggested by Jöreskog and Sörbom (1996) has to be >0.50, for a model to be a good fit. For the proposed model, actual values of RMSEA and PCLOSE fulfil the requirement for a good fit model. Hence, it could be concluded that the model has a good fit and further results are reliable.

Table 6: Model Fit Indices

\begin{tabular}{|l|c|c|c|}
\hline \multirow{2}{*}{ Index } & \multicolumn{3}{|c|}{ Model } \\
\cline { 2 - 4 } & $\begin{array}{c}\text { Default } \\
\text { Model }\end{array}$ & $\begin{array}{c}\text { Satu- } \\
\text { rated } \\
\text { Model }\end{array}$ & $\begin{array}{c}\text { Indepen- } \\
\text { dence } \\
\text { Model }\end{array}$ \\
\hline \multicolumn{4}{|c|}{ I. CMIN } \\
\hline NPAR & 81 & 300 & 24 \\
\hline CMIN & 287.653 & 0.000 & 4528.434 \\
\hline DF & 219 & 0 & 276 \\
\hline P & 0.001 & & 0.000 \\
\hline $\begin{array}{l}\text { CMIN/ } \\
\text { DF }\end{array}$ & 1.313 & & 16.407 \\
\hline
\end{tabular}

\begin{tabular}{|l|c|c|c|}
\hline \multicolumn{5}{|c|}{ II. RMR, GFI } \\
\hline RMR & 0.02 & 0.000 & 0.16 \\
\hline GFI & 0.916 & 1.000 & 0.217 \\
\hline AGFI & 0.885 & & 0.149 \\
\hline PGFI & 0.669 & & 0.2 \\
\hline \multicolumn{4}{|c|}{ III. Baseline Comparisons } \\
\hline $\begin{array}{l}\text { NFI } \\
\text { Delta1 }\end{array}$ & 0.936 & 1.000 & 0.000 \\
\hline $\begin{array}{l}\text { RFI } \\
\text { rho1 }\end{array}$ & 0.92 & & 0.000 \\
\hline $\begin{array}{l}\text { IFI } \\
\text { Delta2 }\end{array}$ & 0.984 & 1.000 & 0.000 \\
\hline $\begin{array}{l}\text { TLI } \\
\text { rho2 }\end{array}$ & 0.98 & & 0.000 \\
\hline CFI & 0.984 & 1.000 & 0.000 \\
\hline \multicolumn{4}{|c|}{ IV. RMSEA } \\
\hline RMSEA & 0.035 & & 0.244 \\
\hline LO 90 & 0.023 & & 0.238 \\
\hline HI 90 & 0.045 & & 0.251 \\
\hline PCLOSE & 0.992 & & 0.000 \\
\hline
\end{tabular}

Source: Analysis of primary data.

\section{Regression Paths and the Standardised Regression Weights}

For the proposed model, it is found from the results as presented in Table 7 that agrifairs of SKDRDP have a significant positive impact on the agricultural activities, social capital, financial status and empowerment of rural population in the study area. Among these four different dimensions of well-being of the rural population, empowerment has the largest size of the impact of agri-fairs. It is found from the results that 96 per cent 
improvement in the empowerment standards of theirs is defined collectively by Krishi Mela activities. Even their increased financial status owes significantly (73 per cent) to Krishi Melas. Krishi Melas also contributed to building social capital and agriculture development. The size of the impact of Krishi Melas on them appears to be comparatively lesser (61 per cent and 59 per cent, respectively) but the impact is statistically significant. The regression path shows the direction of the flow of cause and effect relationships among the factors and variables in this case. The impact flows, in the initial stage, from Krishi Melas to various constructs/factors and in the later stage from the factors/constructs to various growth variables.

Analysing from the perspectives of the impact of Krishi Melas on the different variables relating to the growth factors, it could be noted that Krishi Melas have the highest positive impact on introducing new agricultural practices to poor farmers and labourers. Ninety-two per cent of learnings on new agricultural practices are defined by the Krishi Melas. Motivation to adopt modern techniques of cultivation, improved awareness on various aspects of cultivation, knowledge and application of scientific farming and learning of new farming skills (all relating to agriculture) are the other prominent variables defined to a larger size by the programmes of Krishi Melas. Increased use of toilets and sanitation units which build up social capital in the villages of the study area are mainly due to the awareness creation and support provided by the SKDRDP and its Krishi Mela activities. Krishi Melas account for 88 per cent change in the sanitation standards in the study region.

The growth variables which are influenced the least by Krishi Melas are self-employment, financial status, conservation of soil and water and motivation to save income. Despite being the least influenced variables, the impact of Krishi Melas is statistically significant on them and more than 50 per cent of changes in each of these variables is defined by Krishi Melas.

The final growth model of Krishi Melas is presented in Figure 2. The model exhibits that Krishi Melas have contributed positively to the empowerment of rural people in the study area, building of needful social capital, raising the financial status and contributing to agricultural development. The higher empowerment of rural people, especially women, owing to Krishi Melas is reflected in the form of increased feel of security and confidence, peaceful and happy family atmosphere, improved standard of living, improved self-dependency, ability to make decisions of their life, freedom to do what they wish to do, realisation of meaning, value and purpose in their life, sense of responsibility towards family and society and raised status in the society. From the field survey, it has been observed that participation of women, farmers, labourers and rural people in the Krishi Melas fosters their confidence and enables their empowerment. They feel united and secured with the constant support 
Table 7: Regression Paths and Regression Weights (Default Model)

\begin{tabular}{|c|c|c|c|c|c|c|c|c|}
\hline Factor/Variable & Path & & $\begin{array}{l}\text { Esti- } \\
\text { mate }\end{array}$ & S.E. & C.R. & $\mathbf{P}$ & $\begin{array}{l}\text { Wei- } \\
\text { ght }\end{array}$ & Rank \\
\hline Agriculture & $<---$ & Krishi Melas & .760 & .126 & 6.014 & $* * *$ & .558 & 4 \\
\hline Social Capital & $<<--$ & Krishi Melas & .750 & .114 & 6.590 & $* * *$ & .612 & 3 \\
\hline Financial & $\begin{array}{l}<-- \\
\end{array}$ & Krishi Melas & 1.000 & & & & .729 & 2 \\
\hline Empowerment & $<---$ & Krishi Melas & 1.208 & .170 & 7.119 & $* * *$ & .962 & 1 \\
\hline Conservation & $<---$ & Agriculture & 1.000 & & & & .570 & 21 \\
\hline Organic Farming & $<---$ & Agriculture & 1.131 & .105 & 10.758 & $* * *$ & .680 & 16 \\
\hline Scientific Farming & $<---$ & Agriculture & 1.470 & .141 & 10.453 & $* * *$ & .889 & 4 \\
\hline $\begin{array}{l}\text { Cultivation Tech- } \\
\text { niques }\end{array}$ & $<---$ & Agriculture & 1.563 & .147 & 10.647 & $* * *$ & .918 & 2 \\
\hline Agri-Practices & $<--$ & Agriculture & 1.565 & .147 & 10.673 & $* * *$ & .922 & 1 \\
\hline Farming Skills & $<---$ & Agriculture & 1.455 & .142 & 10.259 & $* * *$ & .859 & 6 \\
\hline $\begin{array}{l}\text { Farming Knowl- } \\
\text { edge }\end{array}$ & $<---$ & Agriculture & 1.478 & .140 & 10.591 & $* * *$ & .898 & 3 \\
\hline Happy Home & $<---$ & Empowerment & 1.000 & & & & .676 & 17 \\
\hline $\begin{array}{l}\text { Security \& Confi- } \\
\text { dence }\end{array}$ & $<---$ & Empowerment & .958 & .077 & 12.486 & $* * *$ & .717 & 11 \\
\hline Standard of Living & $<--$ & Empowerment & 1.022 & .074 & 13.735 & $* * *$ & .775 & 10 \\
\hline Self-Dependency & $<--$ & Empowerment & 1.008 & .102 & 9.867 & $* * *$ & .696 & 12 \\
\hline Decision Making & $<---$ & Empowerment & .952 & .098 & 9.695 & $* * *$ & .687 & 15 \\
\hline Freedom & <--- & Empowerment & .964 & .099 & 9.705 & $* * *$ & .687 & 15 \\
\hline Meaning \& Value & $<---$ & Empowerment & .959 & .107 & 8.919 & $* * *$ & .675 & 18 \\
\hline Responsibility & $<---$ & Empowerment & 1.189 & .107 & 11.083 & $* * *$ & .805 & 8 \\
\hline Social Status & $<---$ & Empowerment & 1.111 & .114 & 9.779 & $* * *$ & .693 & 13 \\
\hline Health Awareness & $<---$ & Social Capital & 1.000 & & & & .688 & 14 \\
\hline Hygiene & <--- & Social Capital & .992 & .093 & 10.643 & $* * *$ & .821 & 7 \\
\hline Sanitation & $<---$ & Social Capital & 1.084 & .105 & 10.306 & $* * *$ & .876 & 5 \\
\hline Education & $<---$ & Social Capital & .927 & .102 & 9.106 & $* * *$ & .654 & 19 \\
\hline Income & $<---$ & Financial & 1.000 & & & & .780 & 9 \\
\hline Finance & $<--$ & Financial & .839 & .111 & 7.550 & $* * *$ & .536 & 22 \\
\hline Savings & $<---$ & Financial & .747 & .090 & 8.282 & $* * *$ & .599 & 20 \\
\hline Self-Employment & <--- & Financial & .898 & .119 & 7.555 & **** & .526 & 23 \\
\hline
\end{tabular}

Source: Analysis of primary data. 
of SKDRDP. Women, who are locked up inside the four walls of the house, are now attending lectures, demonstrations, exhibitions and start dreaming about their future and their dreams are realised with the support of SKDRDP. Sessions on social evils at Krishi Melas, training imparted to women to educate their family and organising de-addiction camps appear to be creating a peaceful and happy family atmosphere.

Krishi Melas, in addition to contributing agricultural development, also has the objective of improving the financial status of the poor rural people. As shown in the model, Krishi Melas have been a powerful intervention of SKDRDP in raising the financial and economic capabilities of the study population. The Krishi Melas have educated people on the opportunities and prospects of self-employment and provided training for the interested. Venturing into various economic activities following Krishi Melas and regular guidance of SKDRDP have made people earn a livelihood (income) on their own. Teachings of Krishi Melas on the importance of savings for future motivated people to save cash and also savings in bank accounts. Unlike the past decades, banks offer loans to farmers and labourers and this has been facilitated by Krishi Mela. Krishi Melas link participants with the banks for easy and institutional finance, thereby enabling them to avail much needed credit facilities.
Krishi Melas organise events and programmes to sensitise rural people on varied social issues aiming at building future social capital. Talks by guests and experts, panel discussions, peer networking, documentary displays, street plays, dramas, etc., are the techniques of interventions to sensitise people. The results found that such interventions of SKDRDP Krishi Melas have significantly contributed to building of social capital by raising the awareness of the people on good health practices and importance of hygiene, increasing awareness of sanitation and reduced open defecations in the villages and also contributed towards education by motivating people to send children to schools.

It is also evident from the final model that agricultural development draws significantly from the Krishi Mela-related programmes. The technical sessions on varied topics of cultivation, crop rotation, mixed farming, fertilisation, irrigation, screening of related documentaries, talks by experts, progressive farmers, exhibitions and demonstrations of farm equipment and technologies have contributed significantly to improve the awareness of rural farmers on various aspects of cultivation, learning of better skills of cultivations, knowing and adopting new agricultural practices, using modern techniques of cultivation and effectively guided them on scientific farming. Farmers in the study region owe the use of farm 
machinery, technologies in agri-processing, scientific dairying, crop rotation and cultivation, dryland farming, etc., to SKDRDP sponsored Krishi Melas.

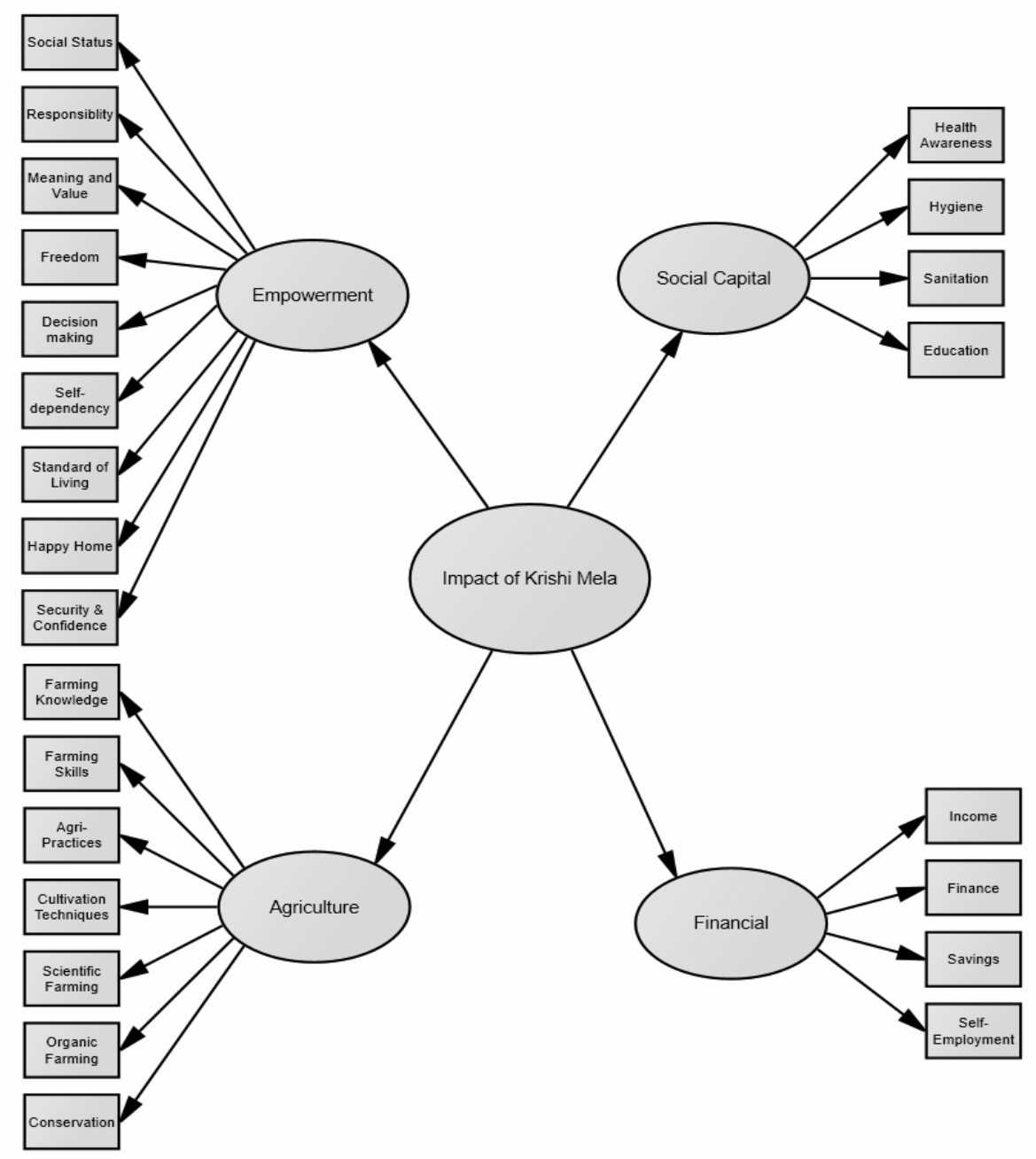

Source: Extracted from primary data using CFA.

Figure 2: Growth Model of Krishi Mela - Final 


\section{Hypotheses Testing}

The study has formed a few hypotheses and later they are tested using $p$-values of the regression coefficient. The summary of the results is presented in Table 8 . The results indicate that Krishi Melas have a significant impact on multi-dimensions of the well-being of poor people which in aggregate contributed to inclusive rural development.

\section{Conclusion and Implications}

The exploratory and empirical analyses adopted in the study provide evidence to conclude that SKDRDP Krishi Melas significantly improved the capabilities of rural households. This is pertinent to note that the development drawn from Krishi Melas are multi-dimensional and the benefit procured is not merely economic in nature. They have enabled the empowerment of rural people, especially women. The results of the study represent the women sine 85 per cent of the survey informants were women participants of Krishi Melas. It is found that Krishi Melas contributed to building of much needed social capital in villages and guided agricultural development. However, the size of the impact of Krishi Melas on varied aspects of well-being is not uniform but differs.

The achievements in rural areas relating to the following well-being aspects are largely

Table 8: Results of Testing of Hypotheses

\begin{tabular}{|c|l|c|c|c|}
\hline No. & Description of Hypotheses & $\begin{array}{c}\text { p-val- } \\
\text { ue }\end{array}$ & $\begin{array}{c}\text { Deci- } \\
\text { sion }\end{array}$ & \multicolumn{1}{|c|}{ Inference } \\
\hline H1 & $\begin{array}{l}\text { Krishi Melas do not have a } \\
\text { significant impact on agricul- } \\
\text { ture and its related variables }\end{array}$ & 0.0001 & Reject & $\begin{array}{l}\text { Krishi Melas have a significant } \\
\text { impact on agriculture and its } \\
\text { related variables }\end{array}$ \\
\hline H2 & $\begin{array}{l}\text { Krishi Melas do not signifi- } \\
\text { cantly influence the empow- } \\
\text { erment of rural people and } \\
\text { its related variables }\end{array}$ & 0.0001 & Reject & $\begin{array}{l}\text { Krishi Melas significantly } \\
\text { influence the empowerment } \\
\text { of rural people and its related } \\
\text { variables }\end{array}$ \\
\hline H3 & $\begin{array}{l}\text { Krishi Melas do not have a } \\
\text { significant impact on rural } \\
\text { social capital and its related } \\
\text { variables }\end{array}$ & 0.0001 & Reject & $\begin{array}{l}\text { Krishi Melas significantly im- } \\
\text { pact rural social capital and its } \\
\text { related variables }\end{array}$ \\
\hline H4 & $\begin{array}{l}\text { Krishi Melas do not have a } \\
\text { significant impact on the fi- } \\
\text { nancial \& economic well-be- } \\
\text { ing of rural people and its } \\
\text { related variables }\end{array}$ & 0.0001 & Reject & $\begin{array}{l}\text { Krishi Melas significantly } \\
\text { impact financial \& economic } \\
\text { well-being of rural people and } \\
\text { its related variables }\end{array}$ \\
\hline
\end{tabular}


attributed to Krishi Melas and follow-up programmes of SKDRDP: rapid movement in application of new agricultural practices and cultivation techniques, increasing awareness on modern and scientific farming, growing awareness and measures taken for hygiene and sanitation, raised level of application of skills in farming and becoming more responsible towards family and society.

Krishi Melas and the follow-up activities of SKDRDP account moderately to the following - aspects of the people in rural areas: improved income of the family, increased standard of living, confidence and security, self-dependency, improved social status, raised awareness towards health, ability to make decisions, freedom of leading the life of choice, awareness and adoption of organic farming, creation of peaceful and happy family atmosphere, realisation of meaning and value to one's own life, especially to the women, and motivation to educate children.

The improvement in financial and economic aspects of well-being of rural people is attributed the least to Krishi Melas. Compared to other aspects, promotion of savings, accessibility to institutional finance and guidance and actions towards selfemployment to rural people are less benefited from Krishi Melas. Even the conservation of water and soil did not have much impact from Krishi Melas. Despite being least affected, the impact of Krishi Melas on them is significant.

The study could not prove the assumption of the proposed growth model of Krishi Melas that participation of various government departments and authorities in the Krishi Mela events would enable in drawing more government benefits, especially in infrastructure sector (roads, electricity, water supply, regular supply of quality seeds and fertilisers, etc.) to the rural areas.

SKDRDP is a pioneer in organising Krishi Melas in Karnataka State. The study reflects the potential of Krishi Melas in influencing the well-being of the grassroots population. They have emerged as a powerful socio-economic movement in the State. They are potential platforms to reduce gender gaps, income gaps, status gaps, etc., and balance the society. Hence, it is suggested that SKDRDP may organise Krishi Mela at each cluster of villages of its project area; following Krishi Mela it may organise extension programmes on the same, especially on environmental conservation as the current impact is lesser, and since SHG network is powerful, the implementation of SKDRDP resolutions could be through them with grading of the SHGs and linking to benefit deliveries. It is also suggested to extend SKDRDP Krishi Melas to other parts of the country primarily to North and NorthEast, mainly with the collaboration of local organisations.

The SKDRDP Krishi Mela could be a model of growth for government and nongovernment organisations. The Panchayati Raj system in India may adopt this model. The 
government programmes on agriculture could be delivered through Krishi Melas at Panchayat level. This would also connect policymakers to the real challenges being faced by the farmers and labourers. Further, organising Krishi Melas in their jurisdiction annually can be a source of revenue generation through sponsorship, rent, etc., to the Panchayats. The Central and State governments may collaborate with SKDRDP to organise Krishi Melas in different parts of the nation with a special focus on agrarian and backward regions on a regular basis. SKDRDP can also be used as a consultant to the government and non-government organisations to organise Krishi Melas in different parts of the country.

The future studies may investigate the impact of Krishi Melas on various other qualitative factors such as culture, tradition, native entrepreneurship, native art, native sports and games, etc., with extended study area and sample size.

\section{References}

Akshatha, B.G and Akash, S.B (2014), "Evaluating the Relevance of ShriKshethra Dharmasthala Gramabhivruddhi Yojana in Rural Upliftment (A Case Study of Shivamogga District)", Integral Review- $A$ Journal of Management, 7 (2): pp.32-46.

Belli, S. Eswar Kumar and Raghvendra, T.S. (2014), "Role of Shri Kshetra Dharmasthala Rural Development Project (SKDRDP) in Micro Finance Through SHGs -A Study in Shimoga District of Karnataka", IOSR Journal of Economics and Finance, 3(2): pp.53-59.

Bentler, P.M (1990), "Comparative Fit Indexes in Structural Models", Psychological Bulletin, 107: pp.238-246.

Browne, M.W and Cudeck, R (1993), "Alternative Ways of Assessing Model Fit" in "Testing Structural Equation Models", Edited by Bollen, K.A. and Long, J.S, Sage, Newbury Park, CA, pp.136-162.

Cronbach, L. J (1970), “Essentials of Psychological Testing”, Harper \& Row, New York.

D'Souza. Sunil, Chidananda. H. L, Udayachandra. P.N and Devaraja.T.S (2013), "BC Model for Inclusive Growth - Study on Performance of SKDRDP, International Journal of Social Science \& Interdisciplinary Research, 1(10): pp.254-262.

Government of India (2011), "Population Census", Office of the Registrar General \& Census Commissioner, India Ministry of Home Affairs, http://censusindia.gov.in/ 
Government of India (2016), Written Statement Issued by the Government of India in the Parliament on May 10.http://timesofindia.indiatimes.com/city/delhi/Big-gap-in-per-capitaincome-in-urban-and-rural-areas/articleshow/52207415.cms

Honnappa, S and Basupattad, Vinod (2016), "Financial inclusion through SHG-BLP: A Study of SKDRDP SHGs in Selected Districts in Hubli Region", International Journal of Commerce and Management Research, 2(9): pp.104-109.

Hu, L.T and Bentler, P. M (1995), “Evaluating Model Fit" in "Structural Equation Modeling:Concepts, Issues, and Applications", Edited by R. H. Hoyle, Sage, London, pp. 76-99.

Hu, L., \& Bentler, P. M (2009), "Cut-off criteria for Fit Indexes in Covariance Structure Analysis: Conventional criteria versus new alternatives", Structural Equation Modeling, http://dx.doi. org/10.1080/10705519909540118

India Microfinance (2015), "Report on Microfinance", by Association of Community Development Finance Institutions and NABARD, http://indiamicrofinance.com

Jackson, L. Dennis, J. Arthur Gillaspy, Jr. and Rebecca Purc-Stephenson (2009), "Reporting Practices in Confirmatory Factor Analysis: An Overview and Some Recommendations", Psychological Methods, 14(1): pp.6-23.

Jöreskog, K.G and Sörbom, D (1996), "LISREL 8 User's reference guide", Scientific Software, Chicago,https://books.google.co.in/books? id=9ACs50RjacC\&printsec=frontcover\&redir_ esc $=\mathrm{y} \# \mathrm{v}=$ onepage $\& \mathrm{q} \& \mathrm{f}=$ false

Joshi, G.V (2012), "Management and Leadership in Rural Development: The Case of SKDRDP", NITTE Management Review, pp.51-72.

Kaiser, H.F (1970), "A Second Generation Little Jiffy", Psychometrika, 35: pp. 401-416.

Kline, R. B (2016), "Principles and Practice of Structural Equation Modelling (4 ${ }^{\text {th }}$ ed.)", Guilford Press, New York.

Priyakumari, S.V. (2015), "A Comparative Study of SHG Organised and Promoted by SKDRDP and Kudumbashree in Dakshina Kannada District and Kollam District, Towards Empowerment of Rural Women", A Minor Research Project Submitted to UGC, http://www.sdmcujire.in/userfiles/MRP/ MRP_priya\%20kumari.pdf 
Shetty, Niranjan and Pinto, Prakash (2015), "Financial Inclusion through SHG-BLP: A Case Study of SKDRDP and NGVCT in India", World Review of Business Research, 5(3): pp. 91-107.

Shylendra H.S., Mukul Kumar and Girish Agrawal (2012), "Enabling Models of Microfinance and Building Social Capital", A Report Submitted to INAFI-India by Institute of Rural Management Anand (IRMA).

SKDRDP (2002), "Participatory Rural Development \& SKDRDP", Newsletter.

SKDRDP (2013), Annual Report, 2012-13.

SKDRDP, (2014), Annual Report, 2013-14.

SKDRDP (2015), Annual Report, 2014-15.

SKDRDP . (2016), Annual Report, 2015-16.

SKDRDP (2017), Report covering data up to November 30, 2016.

SKDRDP (2017), Newsletter, May, https://skdrdpindia.org/blogs/news-letter/

Steiger, J.H and Lind, J.C (1980), "Statistically-based tests for the Number of Common Factors", Paper Presented at the Annual Spring Meeting of the Psychometric Society, lowa City, May 30.

Tucker, L.R and Lewis, C (1973), "A Reliability Coefficient for Maximum Likelihood Factor Analysis", Psychometrika, 38: pp.1-10

Ullman, J. B (2001), "Structural Equation Modelling" in "Using Multivariate Statistics (4th ed.)", Edited by B. G. Tabachnick and L. S. Fidell, Needham Heights, MA: Allyn and Bacon, pp. 653-771. 